\title{
Public health interventions and economic implications due to COVID-19
}

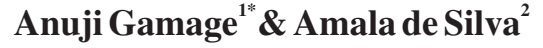 \\ ${ }^{1}$ Department of Public Health and Family Medicine, Faculty of Medicine, General Sir John Kotelawala Defence \\ University, Ratmalana, Sri Lanka; ${ }^{2}$ Department of Economics, Faculty of Arts, University of Colombo, Sri Lanka \\ "Correspondence: anujigamage@gmail.com \\ iDhttps://orcid.org/0000-0002-4713-9283
}

DOI: https://doi.org/10.4038/jccpsl.v26i5.8355

Received on 9 May 2020

Accepted on 8 June 2020

\section{Summary}

The SARS-COV2 virus which is the causative agent of Coronavirus disease 2019 (known as COVID-19) continues to sweep the world, its disease burden and prevention strategies resulting in adverse economic impacts, causing a substantial impact on human lives and even threatening global stability and security (1). The COVID-19 pandemic which is observed in different stages in different part of the world is a tremendous challenge for preventive health sectors all around the world. In this narrative report, we focus on the public health interventions and economic impact from the COVID-19 pandemic in Sri Lanka.

\section{Public health response and its impact}

The World Bank's June 2020 Global Economic Prospects forecast a proposed $5.2 \%$ contraction in global GDP in 2020, with most countries and the globe facing recession, even given the major fiscal and monetary policies being put into place by governments (2). The pandemic will result in deep recession due to the lower investments, erosion of human capital (through lost work and schooling) and the fragmentation of global trade and supply linkages. Emerging market economies and developing countries in particular are likely to be adversely affected due to the pressure on their health systems, loss of trade and tourism, dwindling remittances, restricted capital flows and the tight financial conditions that will need to be imposed amidst mounting debt in these countries (). Table 1 shows International Monetary Fund predictions of impact on global GDP due to COVID-19. COVID-19 resulted in a standstill in economic development due to many factors ranging from preventive measures to halt the spread of the disease severely affecting economic activity, countries facing twin health and funding shocks, to global economic disruptions. 
Table 1: Global growth projection 2019-2021

\begin{tabular}{lccc}
\hline Real GDP & $\mathbf{2 0 1 9}$ & $\mathbf{2 0 2 0}$ & $\mathbf{2 0 2 1}$ \\
\hline World output & 2.9 & -3.0 & 5.8 \\
Advanced economies & 1.7 & -6.1 & 4.5 \\
Emerging and developing Asia (China, India, Asian) & 5.5 & 1.0 & 6.6 \\
Emerging and developing Europe (Russia) & 2.1 & -5.2 & 4.2 \\
Middle East and Central Asia & 1.2 & -2.8 & 4.0 \\
Low-Income and developing countries & 5.1 & 0.4 & 5.6 \\
\hline
\end{tabular}

Source: International Monetary Fund (3)

In a pandemic, the ultimate goal of any country is to halt the spread or maintain a zero-local transmission. In the absence of drugs or a vaccine, countries have to rely on public health measures, and different countries have adhered to different measures in their fight against this global threat. A key activity of epidemiologists is to describe the distribution of disease according to time, place and person, and to help policy makers implement effective measures to prevent the disease (4).

The actual and precise impact due to the current pandemic could vary based on many factors such as the viral behaviour, societal interventions, and treatment of infection. Prof. Chris Whitty points out that an outbreak could result in high mortality and morbidity in the following ways: direct morbidity and mortality due to COVID-19 infection; indirect morbidity and mortality due to health systems being overwhelmed; indirect deaths due to the delay of non-urgent services such as screening or people not seeking health due to the avoidance of hospitals; and most importantly, the suppression and mitigation measures put in place by the government causing wide adverse economic and societal impact leading to poverty and deprivation which is directly linked to ill health (5).

Suppression strategies aim to minimize spread and thereby the number of cases to an absolute minimum for as long as possible. On the other hand, mitigation strategies aim to protect the most vulnerable people in the population (combining isolation of suspect cases, quarantining individuals suspected of carrying the disease, and social distancing of the elderly and others at most risk of severe disease) to control the epidemic so that herd immunity can be acquired by the rest of the population. Hence, mitigation allows

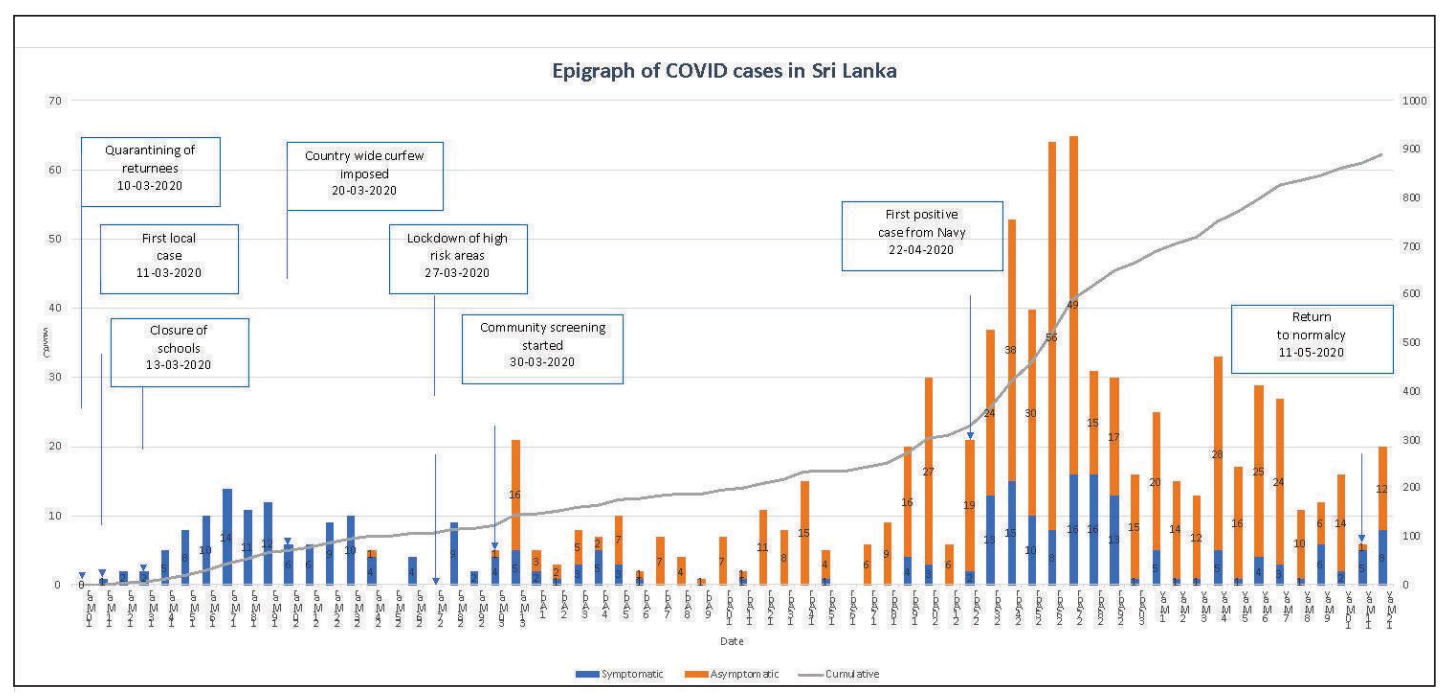

Figure 1: Distribution of COVID-19 positive cases, cumulative cases, nd the public health measures taken in Sri Lanka

Source: Analysed using data from Epidemiology Unit (6) 
the infection to spread at a controlled rate, ensuring that there will be no overburdening of hospitals. These preventive measures too have costs as it leads to substantial economic and social costs, which negatively impacts a country in the short and may be in the longer-term (4).

Figure 1 shows many suppression and mitigation strategies that were implemented very early on. When the first case was detected, preventive strategies were implemented, and this enabled slowing down the spread and also confining the disease to clusters of transmission.

It is clear from evidence that if the infection was allowed to spread uncontrolled, the number infected, hospitalised and needing critical care and deaths would have been much more globally and locally (7).
Figure 2 shows the total individuals requiring hospitalization and critical care and total deaths by the end of the pandemic in Sri Lanka. These calculations are based on a modelling projection done by Imperial College of the global impact of COVID19 (https://www.imperial.ac.uk/mrc-globalinfectious-disease-analysis/covid-19/report-12global-impact-covid-19/). The graph shows scenarios based on $\mathrm{R}_{0}$ (basic reproduction number) values they have used for calculations 2.4 and 3 . This was the clear public health rationale for Sri Lanka's lockdown policy for 52 days. Failing to do so would have likely resulted in the healthcare system's capacity being overwhelmed. Although the preventive measures did have an impact on the economy it also prevented morbidity and mortality of many.

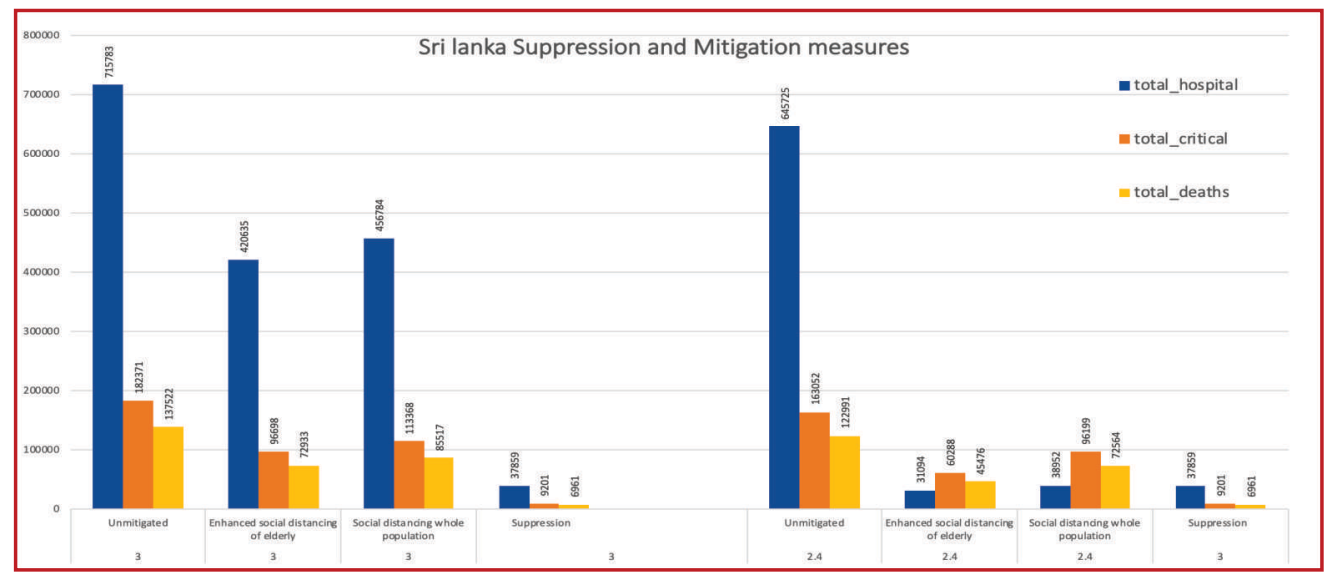

Figure 2: Projected hospitalizations and deaths in Sri Lanka under different mitigation and suppression measures

Source: Calculation based on data from https://www.imperial.ac.uk/mrc-global-infectious-disease- analysis/covid-19 /report-12-global-impact-COVID-19/ (7)

Total death=final total deaths by the end of the pandemic (assuming China-like age-severity profile and health system); total hospital=final total individuals requiring hospitalisation by the end of the pandemic (assuming China-like age-severity profile); total critical=final total individuals requiring critical care by the end of the pandemic (assuming China-like age-severity profile); strategy "unmitigated"=no intervention; social distancing whole population=optimal outcome when epidemic is mitigated interventions to limit contacts in the general population including social distancing; enhanced social distance of elderly=optimal outcome when epidemic is mitigated through interventions to limit contacts in the general population including social distancing, alongside enhanced social distancing of over $70 \mathrm{~s}$

(modelled as a $60 \%$ reduction in contact rate)

As shown in Figure 2, the number of cases expected, and the number observed in Sri Lanka are different. It has to be borne in mind that this could be due to different assumptions (7) made during modelling, the unknown parameters of the pathogen (strain, mutations) and the infection such as the infectivity and infectious period, the number of asymptomatic 
people and the effect suppression, mitigation and the people's own behaviour (social distancing, mask wearing and handwashing towards the disease (4). Additionally, Sri Lanka was able to limit the spread to cluster transmission; if community transmission was to occur, the morbidity and mortality rates would have been higher. As of 31 May 2020, there have been 1633 confirmed cases, with 811 recoveries and 11 deaths in Sri Lanka.

\section{Economic return of disease control}

Human resource is one of the important determinants of economic growth of a country. Figure 3 shows how the control of disease can affect economic growth and highlights the fact that one major channel is labour and its impact on productivity. Human capital is labour enhanced by education, training and good health, and the World Bank is currently stressing human capital as the potential engine for growth for countries like Sri Lanka (8). Disease control results in controlling morbidity and mortality. Labour productivity, and human capital are directly affected by morbidity and mortality. A healthy life lays the groundwork for a population, which is productive, resulting in larger outputs, income and economic growth. Health strategies should not be hampered by merely considering present economic adversities but rather should take into consideration the economic impact over the longer term, particularly given the morbidity and mortality (that would depend on choice of suppression and mitigation strategies) would have an impact on labour and human capital in the long term.

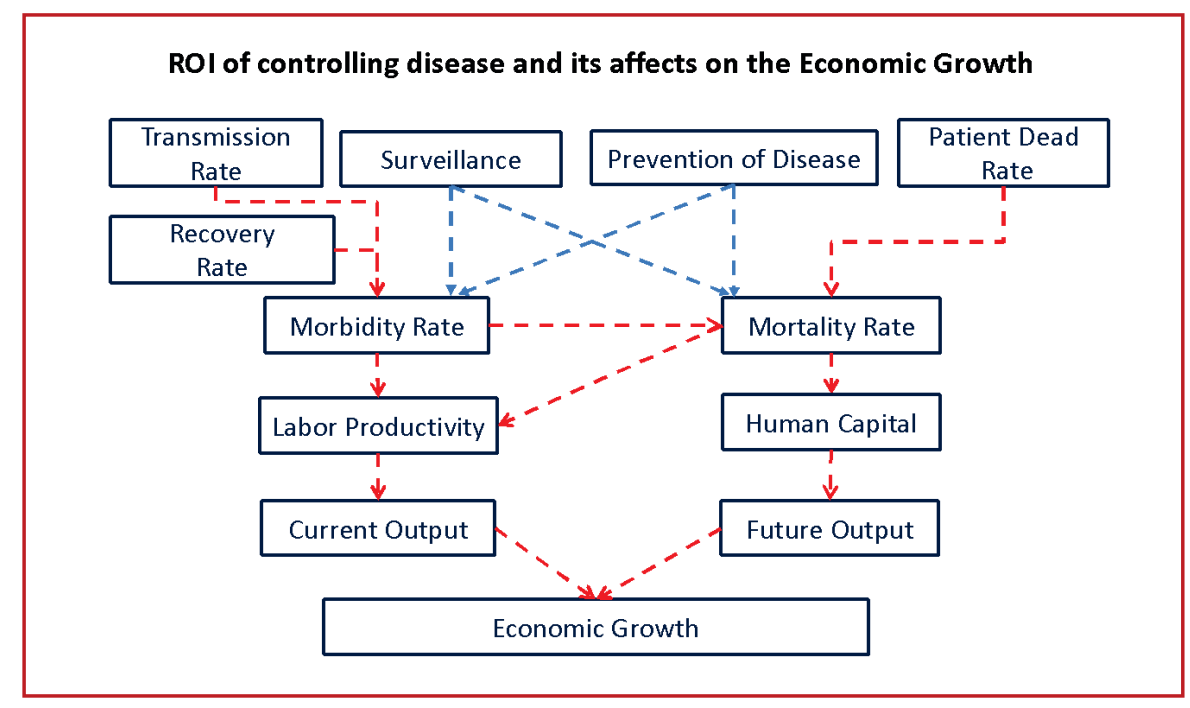

Figure 3: Return of investment of controlling morbidity and mortalit

The economic impact: how the economy reacts to public health interventions?

As shown in Figure 4, economic activities are interconnected, and several channels could affect economic activities of the country during an outbreak such as COVID-19. Households engage in employment and leisure activities to maximise their utility. The producers combine labour and capital to maximise the profit. The government collects taxes to finance the expenditure and redistribute welfare. Although mitigation and suppression of the disease has many positive externalities from a health perspective, economically it has many negative effects. Typically, health shocks tend to be negative and would include declines in domestic demand, supply disruption, changes in consumption patterns and investment. Mandatory quarantine, selfisolation and lock down due to COVID-19 could result in substantial economic impact in Sri Lanka. However, the magnitude of the impact would depend on several key factors which include the viral behaviour, government policies and the reaction of firms and households (4, 9-10). 


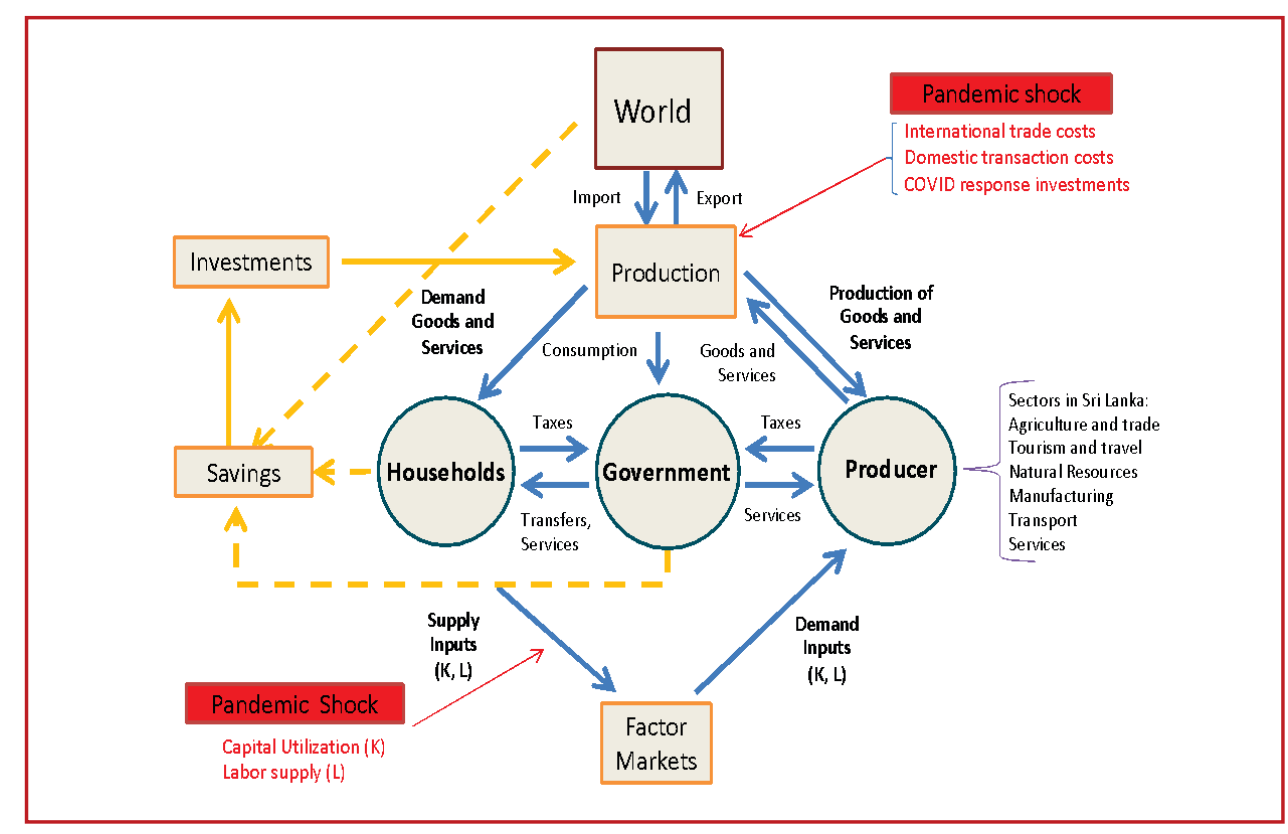

Figure 4: A linkage model to show economic consequences of a pandemic

\section{Discussion}

Controlling the COVID-19 epidemic was achieved using public health interventions, but it has left the economy in a worse state. Even prior to the epidemic, Sri Lanka was facing severe fiscal problems and macroeconomic instability. The pandemic worsened this situation: particularly through reduction of employment. In this context, the most salient issue is that around $58 \%$ of employees in the country belong to the informal work sector (11); and while agricultural workers were allowed to continue with their occupation, most of the others had no work and an income during this period. The state attempted to compensate through providing a Rs 5000 (US\$26.9) handout but this was only a partial solution given the numbers covered and the amount provided. This measure increased government expenditure, in addition to higher expenditure on health and tax revenue being adversely affected during the same period, worsened the budget deficit, while expansionary monetary policy (Central Bank of Sri Lanka) could lead to inflationary pressures that would also adversely affect economic conditions in the country (12-13).

Gourinc has stated "the real danger is that the virus mutates and infect our economic system even as we manage to root it out of our bodies"(10). The future is uncertain and more so with the current pandemic, as the country was very dependent on imports, exports and tourism at the point of the pandemic. As mentioned afore, modern world and the economy is a complex web of inter-connections and hence a sudden shock could initiate a cascade of events; the future will now have to be viewed differently, and a major need has emerged for rethinking economic policy. Sectorally in the agricultural sector, the emphasis seems to be on self-sufficiency; with regard to the industrial sector attention is once again being paid to import-substitution, given the state decision to curtail all non-essential imports. The biggest challenge is for the service sector: tourism is likely to be non-existent in the coming months while a major change in the nature of tourism may occur in the long run. Similarly, changes have occurred in retail trade and distribution of goods and these issues may need to be focused on in attempting to reduce the negative impact on the small-scale operators. The impact on the poor will have to be focused on, whether it be in terms of unemployment or self-employment, so as to safeguard this social group from long term impacts of chronic poverty.

Technological advancements are proposed as a means of responding to the pandemic, the main idea 
being innovations that replace labour with capital, allowing for social distancing and public health practices. The technological transformation will benefit some important businesses, particularly the technology business and would be a disadvantage for other businesses. The transformation could affect blue collar employment adversely. Businesses that were affected by two months of lay-off would be faced with the challenge of finding the finances to mechanize production processes. On the other hand, the shift to working from home in the context of white collar workers, that has been necessitated by the public health response to the epidemic, could be an important turning point for the labour market and the economy: demographic transition is likely to create labour shortages in the future and the fact that more than $2 / 3^{\text {rd }}$ of women are not part of the work force is preventing resolving this issue through larger female employment; the possibility of working from home, as well as the idea of flexi-working time may now seem a more plausible option given the experiences of the past two months. The labour market may now become more flexible, that would be beneficial to the economy in the long run.

Sri Lanka could consider capitalizing on the current global demand i.e. local production of test swabs and viral transport media, personal protective equipment within the local garment industry and many more. Opportunities for these in the global market can be explored and should be promoted.

The state has ordered employers not to lay off workers; and the Central Bank has also advocated that banks and financial institutions provide concessions on paying back loans and leases (12). While these are positive welfare measures, the fact that most workers are in the informal sector, and much of loan taking occurs from informal sources, means that the adverse impacts of the public health interventions resulting in social distancing and lock down can have severe impacts on households in the months to come. The state needs to continue to work to safeguard poor households and small and medium scale enterprises, including informal sector ventures, to mitigate the adverse economic impacts in the future, and to ensure that those pushed into transitory poverty emerge from poverty rather than join the catastrophic poor.

\section{Author Declaration}

Author contributions: AUG and AdeS were involved in planning of the article and in literature search. AUG drafted the manuscript and AdeS was involved in interpreting the data and editing the article. Both authors approved the final manuscript.

\section{References}

1. International Working Group on Financing Preparedness. 2017. From panic and neglect to investing in health security: financing pandemic preparedness at a national level. World Bank, Washington, DC. Available from: https:// openknowledge.worldbank.org/handle/10986/2676 1. Accessed 8 May 2020.

2. Bank W. Global economic prospects. Washington, DC: World Bank, June 2020.

3. IMF. World economic outlook. The great lockdown. In: International Monetary Fund, April 2020.

4. Anderson RM, Heesterbeek H, Klinkenberg D, Hollingsworth TD. How will country-based mitigation measures influence the course of the COVID-19 epidemic? The Lancet 2020; 395(10228): 931-934. DOI: 10.1016/S01406736(20)30567-5.

5. Christopher Whitty. COVID-19: an initial view. Gresham College Lectures 2020, Gresham College. Available from: https://www. gresham.ac.uk/ lectures-and-events/covid-19.

6. Epidemiology Unit. Epidemiology Unit, Ministry of Health Sri Lanka. Ministry of Health, Sri Lanka, updated on March 2019. Available from: https://www.epid.gov.lk /web/index.php?option= com_content $\& v i e w=$ article $\& i d=225 \& l a n g=e n$. Accessed 11 May 2020.

7. Walker PGT, Watson CWO, Baguelin M, Ainslie KEC, Bhatia S, Bhatt S, Boonyasiri A, Boyd O, Cattarino L, Cucunubá Z, et al. Report 12 - The global impact of COVID-19 and strategies for mitigation and suppression. Imperial College London. Available from: https://www.imperial.ac. uk/mrc-global-infectious-disease-analysis/covid19/report-12-global-impact-covid-19/. Accessed 5 May 2020.

8. Lanka WBS. Investment in human capital. South Asia: human development sector. Washington DC: Publisher, 2014. 
9. Martin Wolf. Analysis global economy after the coronavirus pandemic. Financial Times, 13 May 2020. Available from: https://www.ft.com /martinwolf.

10. Pierre-Olivier Gourinchas. Flattening the pandemic and recession curves. In: Policy EEfI, Editor, 2020.

11. Department of Census and Statistics (DCS). Sri Lanka Labour Force Survey Annual Report - 2017. Colombo: Ministry of National Policies and Economics Affairs. Available from: http:// www.statistics.gov.lk/samplesurvey/LFS_Annual\% 20Report_2017.pdf. Accessed 15 May 2020.

12. Central Bank of Sri Lanka. Central Bank of Sri Lanka implements extraordinary regulatory measures to facilitate banks to support COVID-19 affected businesses and individuals 2020. Available from: https://www.cbsl.gov.lk/en /news/central_bank_ of_sri_lanka_implements_extraordinary_regulatory _measures_to_facilitate_banks_to_support_covid_ 19_affected_businesses_and_individuals. Accessed 30 March 2020.

13. Central Bank of Sri Lanka. The Central Bank of Sri Lanka Eases Monetary Policy Further to Support Economic Activity amidst the Spread of the COVID19 Pandemic 2020. Available from: https://www. cbsl.gov.lk/en/news/cbsl-eases-monetary-policystance-amidst-covid-19-pandemic. Accessed 16 March 2020. 